\title{
Outcomes of an indian intensive care unit in a tertiary hospital - a prospective observational study
}

S Jakkinaboina*, P Peddapyata, S Paul, R Celerappa, M Aleem

From ESICM LIVES 2015

Berlin, Germany. 3-7 October 2015

\section{Introduction}

The mortality and morbidity of the patients admitting to the intensive care unit is high all over world. The evidence based treatment can improve the outcomes in the intensive care unit.

\section{Objectives}

The objectives of this study were to evaluate the effect of an in-hospital mortality and morbidity for the patients admitting to the intensive care unit in a tertiary care hospital with adherence to evidence-based guidelines.

\section{Methods}

All the patients admitted to the ICU are enrolled except post cardiac arrest and paediatric patients. A prospective study was done for a period of 6 months from Feb 2014 to Aug 2014. The data was collected from patient records after ethics committee approval. The primary end point was in-hospital mortality. The secondary outcomes were hospital and ICU length of stay.

\section{Results}

The total number of patients enrolled are 486 .

Table 1 shows the data of the overall patients in the group.

The in-hospital mortality is $7.41 \%$. The most common admission diagnosis is shock. Most common comorbidities are Diabetes and hypertension (38.68\%) followed by diabetes(10.7\%). Neutropenia is present in $2.88 \%$ patients. $80.25 \%$ patients received antibiotics before admission to ICU, Most common antibiotics used are BL+BLI (57.61\%) combination followed by carbapenems (14.82\%). Most common organ failure is lung (23.87\%)

Apollo Health City, Critical Care Medicine, Hyderabad, India
Table 1. Data of the overall patients admitted to the ICU

\begin{tabular}{lll}
\hline Variable & Mean $\mathbf{n}$ & standard deviation, (\%) \\
\hline Age in years & 55.42 & 17.5 \\
\hline ICU length of stay in days & 3.52 & 3.2 \\
\hline Hospital length of stay in days & 9.11 & 9.24 \\
\hline APACHE II Score & 14.72 & 8.2 \\
\hline SOFA Score & 8.33 & 4.2 \\
\hline Male sex & 282 & $(58.02)$ \\
\hline Medical patients & 386 & $(79.42)$ \\
\hline Vasopressors & 152 & $(31.28)$ \\
\hline Mortality & 36 & $(7.41)$ \\
\hline
\end{tabular}

followed by Renal failure(23.46\%). RRT given for $22.22 \%$ patients. Tracheostomy was done in $4.53 \%$ patients. The factors which increased the mortality are increased ventilator days, increased APACHE II and SOFA score, shock as the diagnosis, comorbidities both diabetes and hypertension, presence of neutropenia, reintubation, sepsis, antibiotics before admission to hospital, lung and renal as organ failures and use of renal repalcement therapy. Almost the same factors increased the ICU and hospital length of stay. The ICU acquired infection total are 20patients (4.12\%) has 65\% ESBL(E. Coli, kleibsiella), MDR 25\% (Kleibsiella, psedomonas) MRSA 5\%, MSSA $2 \%$, Fungal infections $3 \%$. The hospital acquired infection (other wards) 12 patients(2.47\%) with ESBL 70\% and $30 \%$ are MDR organisms. The community acquired infections are 30\% non ESBL, 40\% ESBL, MDR 10\% and remaining $20 \%$. The data of survivors and non survivors are in table 2.

The overall group mortality is $7.41 \%$ (36 patients) in our study is far less than calculated as per APACHE II is $18.6 \%$ for the infection. 
Table 2. The variables between survivors and nonsurviors

\begin{tabular}{llll}
\hline Variable & Non surviors & Surviors & p Value \\
\hline Ventilator days & 2.56 & 0.59 & 0.001 \\
\hline APACHE II SCORE & 27.06 & 13.73 & 0.001 \\
\hline SOFA SCORE & 10.94 & 8.12 & 0.001 \\
\hline Neutropenia & 6 & 8 & 0.001 \\
\hline Reintubation & 4 & 10 & 0.001 \\
\hline ICU length of days & 3.39 & 3.53 & 0.79 \\
\hline Renal replacement therapy & 22 & 86 & 0.001 \\
\hline Vasopressors & 36 & 116 & 0.002 \\
\hline Sex Male / female & $20 / 16$ & $262 / 188$ & 0.76 \\
\hline
\end{tabular}

Table 3. The data of the various group of sepsis patients

\begin{tabular}{llllllllll}
\hline Group & $\begin{array}{l}\text { Age in } \\
\text { years }\end{array}$ & $\begin{array}{l}\text { ICU length of } \\
\text { days }\end{array}$ & $\begin{array}{l}\text { number of } \\
\text { patients }\end{array}$ & $\begin{array}{l}\text { Hospital length } \\
\text { of days }\end{array}$ & $\begin{array}{l}\text { Ventilator days } \\
\text { mean }\end{array}$ & $\begin{array}{l}\text { APACHE II } \\
\text { Score }\end{array}$ & $\begin{array}{l}\text { SOFA } \\
\text { Score }\end{array}$ & $\begin{array}{l}\text { Neutropenia } \\
\text { Mortality } \\
\text { \% }\end{array}$ \\
\hline No Sepsis & 52.2 & 3.2 & 274 & 9.58 & 0.58 & 12.23 & 7.72 & 6 & 4.37 \\
\hline Septicshock & 58.94 & 3.73 & 148 & 8.47 & 0.9 & 18.18 & 9.36 & 8 \\
\hline $\begin{array}{l}\text { Severe } \\
\text { Sepsis }\end{array}$ & 64.83 & 4.83 & 24 & 9.33 & 0.17 & 16.25 & 7.58 & 0 & 0 \\
\hline Sepsis & 58 & 4.5 & 40 & 7 & 4 & 17.5 & 8.5 & 0 \\
\hline
\end{tabular}

212 sepsis patients are present in this study divided into different groups. The remaining patients are 274 which are grouped as no sepsis patients. These are represented in table 3 .

\section{Conclusions}

The mortality and morbidity in our ICU is less compared with standard scoring systems APACHE II and SOFA. The infection rate in the ICU is less, but more resistant organisms are present. We need measures to decrease the resisstant organisms.

Published: 1 October 2015

\section{Reference}

1. Characteristics and outcomes for critically ill patients in ICU. Crit Care Med 2005, 33(9):1922-7, Sep.

doi:10.1186/2197-425X-3-S1-A760

Cite this article as: Jakkinaboina et al:: Outcomes of an indian intensive care unit in a tertiary hospital - a prospective observational study.

Intensive Care Medicine Experimental 2015 3(Suppl 1):A760.

\section{Submit your manuscript to a SpringerOpen ${ }^{\circ}$ journal and benefit from:}

- Convenient online submission

- Rigorous peer review

- Immediate publication on acceptance

- Open access: articles freely available online

- High visibility within the field

- Retaining the copyright to your article

Submit your next manuscript at $\boldsymbol{s p r i n g e r o p e n . c o m ~}$ 